\title{
Sulfitobacter mediterraneus sp. nov., a new sulfite-oxidizing member of the $\alpha$-Proteobacteria
}

\author{
Rüdiger Pukall, ${ }^{1}$ Daniela Buntefuß, ${ }^{1}$ Anja Frühling, ${ }^{1}$ Manfred Rohde, ${ }^{2}$ \\ Reiner M. Kroppenstedt, ${ }^{1}$ Jutta Burghardt, ${ }^{1}$ Philippe Lebaron, ${ }^{3}$ \\ Laetitia Bernard ${ }^{3}$ and Erko Stackebrandt ${ }^{1}$
}

Author for correspondence: Erko Stackebrandt. Tel : +495312616 352. Fax: +495322616418.
e-mail: erko@dsmz.de

1,2 DSMZ-Deutsche Sammlung von Mikroorganismen und Zellkuilturen $\mathrm{GmbH}^{1}$, and GBF - Gesellschaft für Biotechnologische Forschung $\mathrm{GmbH}^{2}$, D38124 Braunschweig, Germany

3 Laboratoire ARAGO, Université de Paris VI, Equipe de Microbiologie des Milieux Aquatiques, 66651 Banyuls-sur-Mer Cedex, France

\begin{abstract}
Analysis of PCR products of 165 rDNA of 680 isolates from Mediterranean Sea mesocosm experiments with taxon-specific 165 rDNA oligonucleotides revealed that 262 isolates belonged to the $\alpha$ subclass of the class Proteobacteria. Partial 16S rDNA sequence analysis of selected isolates and oligonucleotide probing with a Sulfitobacter-specific 165 rDNA probe affiliated 33 strains to the genus Sulfitobacter. Analysis of the Haelll digest pattern of 165 rDNA revealed the presence of two groups; while 30 strains showed a pattern identical with that obtained for Sulfitobacter pontiacus DSM 10014 ${ }^{\top}$, a second group of three strains had a unique pattern that was different from that of the type strain. Five isolates of group 1 and one isolates of group 2,

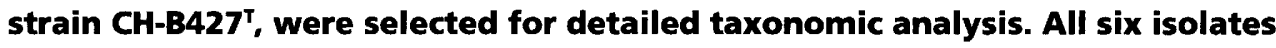
closely resembled the type strain Sulfitobacter pontiacus DSM 10014 in physiological reactions. However, strain $\mathrm{CH}-\mathrm{B427}^{\top}$ differed quantitatively in the composition of fatty acids from Sulfitobacter pontiacus DSM $10014^{\top}$ and showed only 98.2\% 16 S rDNA sequence similarity with strain DSM 10014 ${ }^{\top}$. DNA-DNA reassociation value obtained for strains DSM $10014^{\top}$ and CH-B427 $^{\top}$ revealed $46 \%$ similarity. Based on the results of DNA-DNA reassociation and discrete differences in the nucleotide composition of 16S rDNA, a new species of the genus Sulfitobacter is proposed, designated Sulfitobacter mediterraneus sp. nov., the type strain being strain CH-B427' (= DSM 12244').
\end{abstract}

Keywords: Sulfitobacter mediterraneus, $\alpha$ subclass of Proteobacteria, chemotaxonomy, 16S rDNA analysis

\section{INTRODUCTION}

The past years have shown an increasing interest in the isolation and description of novel bacterial isolates from the marine environment. Several of these new isolates are members of group 3 of the $\alpha$ subclass of the class Proteobacteria in which they are phylogenetically moderately related to members of the genus Roseobacter. Besides many as yet undescribed novel isolates from the Pacific Ocean (Suzuki et al., 1997; Gonzales et al., 1997), Antarctic Sea (Bowman et al., 1997) and the Mediterranean Sea (Benlloch et al., 1995), some

Abbreviation: ARDRA, amplified ribosomal DNA restriction analysis. The EMBL accession number for the $16 \mathrm{~S}$ rDNA sequence of $\mathrm{CH}-\mathrm{B} 427^{\top}$ is Y17387. have been described as members of novel genera, such as Sulfitobacter from the $\mathrm{H}_{2} \mathrm{~S} / \mathrm{O}_{2}$ interface of the Black Sea (Sorokin, 1995), Octadecabacter from Antarctic and Arctic polar sea-ice water (Gosink et al., 1997) and Sagittula from the coast of Georgia, USA (Gonzales et al., 1997).

To increase the chance of obtaining a broad range of culturable aerobic and heterotrophic marine prokaryotes, four mesocosms were established that contained natural seawater from a coastal region at Banyuls-sur-Mer, France (Mediterranean Sea), three of which were subjected to three different eutrophying conditions. A total of 680 strains was isolated from the mesocosm at different time-points and the phylogenetic position of most of them was determined by either partial 16S rDNA sequence analysis or oligo- 
nucleotide probing using taxon-specific 16S rDNA probes (Stackebrandt et al., 1998). The PCR-amplified 16S rDNA of 33 isolates that hybridized with the $\alpha$ Proteobacteria probe (Manz et al., 1992) also hybridized with a Sulfitobacter-specific probe, designed in this study on the basis of the almost complete $16 \mathrm{~S}$ rDNA sequence of Sulfitobacter pontiacus DSM $10014^{\mathrm{T}}$ and partial $16 \mathrm{~S}$ rDNA sequence information obtained from the Mediterranean isolates that shared high sequence similarity with the 16S rDNA of strain DSM $10014^{\mathrm{T}}$. Three of the 33 strains differed significantly from the type strain of Sulfitobacter pontiacus in molecular properties, which indicated that it should not be affiliated to Sulfitobacter pontiacus. In this paper we describe Sulfitobacter mediterraneus sp. nov. and designate strain $\mathrm{CH}-\mathrm{B} 427^{\mathrm{T}}\left(\mathrm{DSM} 12244^{\mathrm{T}}\right)$ as the type strain.

\section{METHODS}

Experimental set-up. The mesocosms, originally set up for studies on the effect of eutrophication processes on the microbial diversity (MAST project CHABADA, project no. MAS3-CT96-0047) and the treatment of the mesocosms have been described previously (Stackebrandt et al., 1998). Each mesocosm was filled with 3001 natural seawater collected from $1 \mathrm{~m}$ depth at a station $\left(42^{\circ} 31^{\prime} \mathrm{N}, 03^{\circ} 11^{\prime} \mathrm{E}\right)$ located about $2400 \mathrm{~m}$ off Banyuls-sur-Mer, France (Mediterranean Sea) and filtered through a $200 \mu \mathrm{m}$ nylon mesh.

Sampling. Samples were taken daily from each mesocosm. Inoculation was done by spreading $100 \mu$ l of seawater onto Marine Agar Difco 2216 (ZoBell's medium) plates. Dilutions were $10^{-1}, 10^{-2}$ and $10^{-3}$. Every dilution was inoculated in triplicate. Between 35 and 50 colonies were selected from each sampling time. Sampling criteria were (i) uniqueness in morphotype and (ii) to verify their similarity, multiple samples $(2-4)$ were selected for those colonies that appeared similar in morphology ( 3 or 4 ). Purification of each colony was done after two successive subcultures in laboratories at Banyuls and Barcelona. Isolates were preserved by (i) freezing in triplicate at $-80^{\circ} \mathrm{C}$ in $40 \%$ glycerol, and (ii) at $20^{\circ} \mathrm{C}$ on marine agar. Strains, abbreviated to $\mathrm{CH}$ followed by the letter of the mesocosm and strain number (e.g. $\mathrm{CH}$ B $427^{\mathrm{T}}$ ), were shipped on marine agar to the DSMZ for subsequent analysis.

Molecular identification. Preparation of genomic DNA from pure cultures was done as described previously (Rainey et al., 1996). Amplified ribosomal DNA restriction analysis (ARDRA) was done by PCR amplification of $16 \mathrm{~S}$ rDNA using $50 \mathrm{ng}$ genomic DNA as target and the primer pair $27 \mathrm{f}$ (5' GAGTTTGATCCTGGCTCAG $3^{\prime}$ ) and 1385 r (5' CGGTGTGT[A/G]-CAAGGCCC 3'). PCR was performed as described by Pukall et al. (1998). 16S rDNA amplicons were cleaved using three different restriction enzymes (HaeIII, Bst UI and HhaI; New England Biolabs). Separation of fragments was performed by agarose gel electrophoresis (2\% Metaphor agarose; FMC Bioproducts) and stained with ethidium bromide. The primer pair $27 \mathrm{f}$ and $1500 \mathrm{r}\left(5^{\prime}\right.$ AGAAAGGAGGTGATCCAGCC 3') was used for the amplification of the almost complete 16S rRNA gene (Lane, 1991). PCR and sequence analysis of $16 \mathrm{~S}$ rDNA was performed as described by Rainey et al. (1996). Partial sequence analysis was performed using the primer $530 \mathrm{r}$ ( $5^{\prime}$ G[T/A]ATTACCG-CGGC[T/G]GCTG 3'). Purified sequence reactions were electrophoresed using an Applied Biosystems model 373A automated DNA sequencer.

Phylogenetic analyses. Sequences were aligned manually with sequences published previously. These were stored in the DSMZ database consisting of more than $500016 \mathrm{~S}$ rDNA sequence entries, including those from the Ribosomal Database Project (Maidak et al., 1997) and EMBL. Similarity values were transformed into phylogenetic distance values that compensate for multiple substitutions at any given site in the sequence (Jukes \& Cantor, 1969). The algorithm of DeSoete (1983) and the neighbour-joining method contained in the PHYLIP package (Felsenstein, 1993) were used in the construction of phylogenetic dendrograms. All analyses were done on a SUN SparcII workstation.

Oligonucleotide hybridization. PCR products were purified with the Prep-A-Gene DNA Purification Kit and eluted in $50 \mu l$ water. Three microlitres of each of the $16 \mathrm{~S}$ rDNA PCR products was denatured by heating and $1 \mu \mathrm{l}$ of each sample was applied to a nylon membrane (Hybond-N; Amersham) and fixed by UV $(260 \mathrm{~nm})$ for $100 \mathrm{~s}$. Hybridization and detection were performed according to the manufacturer's instructions using the DIG Luminescent Detection Kit (Boehringer Mannheim). Oligonucleotide probes were synthesized by the Eurogentec Oligo-Synthesis-Service (Eurogentec) and labelled using the DIG Oligonucleotide 3 '-End Labelling Kit (Boehringer Mannheim). All membranes were processed simultaneously in the same roller tube to ensure reproducible hybridization and detection conditions. Prehybridization was done at $37^{\circ} \mathrm{C}$ for $4 \mathrm{~h}$ according to the manufacturer's instructions (Boehringer Mannheim). The prehybridization solution was replaced by a solution containing the DIG-labelled probe and hybridization was continued at $37^{\circ} \mathrm{C}$ for $16 \mathrm{~h}$. The temperature of the stringency wash in $6 \times \mathrm{SSC}, 0 \cdot 1 \% \mathrm{SDS}$ buffer depended upon the specific $T_{\mathrm{m}}$ of the oligonucleotide probe used. Exposure to X-ray film (Fuji 51209) was up to for $2 \mathrm{~h}$. Probes used were (i) a universal probe G[T/A]ATTACCGCGGC-[T/G]CTG $\left(T_{\mathrm{m}} 59^{\circ} \mathrm{C}\right)$ (Lane, 1991) to determine the accessibility of $16 \mathrm{~S}$ rDNA at the filter, (ii) an $\alpha$-subclassspecific probe CGTTCG[C/T]TCTGAGCCAG $\left(T_{\mathrm{m}} 58^{\circ} \mathrm{C}\right)$ (Manz et al., 1992), and (iii) a Sulfitobacter-specific probe CGCCTGCCCCCCGAAGG $\left(T_{\mathrm{m}} 62^{\circ} \mathrm{C}\right)$ (this study). $T_{\mathrm{m}}$ values were determined as described previously (Lane, 1991).

Determination of base composition of DNA. Isolation of DNA (Cashion et al., 1977) and determination of the DNA mol \% G + C values by HPLC (Mesbah et al., 1989) followed described procedures.

DNA-DNA hybridization. DNA-DNA similarity were performed by the renaturation method (Escara \& Hutton, 1980; Huß et al., 1983). Similarity values were calculated according to the methods of Jahnke (1992).

Extraction and analysis of fatty acids. Fatty acids were determined in cells grown in TSB medium containing $3 \%$ $\mathrm{NaCl}$ and on Marine agar. Fatty acid methyl esters were obtained from freeze-dried biomass (approx. $10 \mathrm{mg}$ ) by saponification, methylation and extraction using the modifications (Kuykendall et al., 1988) of the method of Miller (1982). The fatty acid methyl ester mixtures were separated using a model 5898A microbial identification system (Microbial ID) which consisted of a model 3392 gas chromatograph fitted with a $5 \%$ phenyl-methyl silicone capillary column $(0.2 \mathrm{~mm} \times 25 \mathrm{~m})$, a flame-ionization detector, a model 3392 integrator, model 7673A automatic sampler and a model 900/300 computer (all from Hewlett 
Sulfitobacter mediterraneus sp. nov.

Packard). Peaks were automatically integrated and fatty acid names and percentages were calculated by the identification system. The gas-chromatographic parameters were as follows: carrier gas, ultrahigh-purity hydrogen; column head pressure, $60 \mathrm{kPa}$; injection volume, $2 \mu \mathrm{l}$; column split ratio, 100:1; septum purge, $5 \mathrm{ml} \mathrm{min}^{-1}$; column temperature, $170-270^{\circ} \mathrm{C}$ at $5{ }^{\circ} \mathrm{C} \mathrm{min}^{-1}$; injection port temperature, $250{ }^{\circ} \mathrm{C}$; and detector temperature, $300^{\circ} \mathrm{C}$.

Scanning electron microscopy. Bacteria grown on liquid broth were adsorbed onto poly-L-lysin-coated cover slips, fixed with $3 \%$ glutaraldehyde in PBS for $15 \mathrm{~min}$ at room temperature and washed three times with PBS. Samples were dehydrated with a graded series of acetone $(10,30,5070,90$, $100 \%$ acetone), critical-point dried with $\mathrm{CO}_{2}$ (Balzers CPD030), and sputter-coated with a gold film to approximately $10 \mathrm{~nm}$ thick (Balzers SCD040). Samples were examined in a Zeiss FESEM DSM962 Gemini microscope with $4 \mathrm{~mm}$ working distance and at an acceleration voltage of $5 \mathrm{kV}$ using the In-lens and Everhart-Thornley SE detector in a 75:25 ratio. Pictures were stored digitally and processed using Corel PhotoPaint 7.0.

Physiological studies. Strains tested for the ability to grow at $\mathrm{pH} 6.0,6.5,7.5$ and 8.5 and for $\mathrm{NaCl}$ requirement $(2,5,20$, 50 and $80 \mathrm{~g} \mathrm{l}^{-1}$ ) were cultivated on marine broth medium (Difco). Results were recorded after $3 \mathrm{~d}$ incubation. Growth temperatures were tested on marine agar plates which were incubated in the dark for 1 week at $4,17,28$ and $37^{\circ} \mathrm{C}$. Anaerobic growth was tested on marine agar plates using Anaerocult A (Merck) incubated in an anaerobic jar. Oxidase, catalase and Gram stain reactions, and accumulation of polyhydroxybutyric acid were determined by standard methods (Gerhardt et al., 1994). The existence of flagella was determined by the method of Heimbrook et al. (1989). Following extraction of pigments with 7:2 acetone/ methanol, determination of bacteriochlorophyll $a$ was done spectrophotometrically $(350-950 \mathrm{~nm})$ with a Perkin Elmer model Lambda2 UV/VIS spectrophotometer. Biochemical tests were done using the API 20NE identification system (API bioMérieux) with bacterial suspensions that were washed in $20 \mathrm{~g} \mathrm{l}^{-1}$ sea salt solution (Sigma).

The ability to grow on a variety of carbon sources was tested using (i) a minimal medium with or without addition of yeast extract $\left(0 \cdot 1 \mathrm{~g} \mathrm{l}^{-1}\right)$ containing in $\mathrm{g}^{-1}: \mathrm{MgCl}_{2} .6 \mathrm{H}_{2} \mathrm{O}, 0.6 \mathrm{~g}$; $\mathrm{CaCl}_{2} .2 \mathrm{H}_{2} \mathrm{O}, 0.3 \mathrm{~g} ; \mathrm{Na}_{2} \mathrm{SO}_{4}, 0.7 \mathrm{~g} ; \mathrm{NaCl}, 20.0 \mathrm{~g} ; \mathrm{pH} 7 \cdot 3$, and (ii) a modified, HEPES-buffered medium consisting of $\left(\mathrm{g} \mathrm{l}^{-1}\right)$ : HEPES ( $N$-[2-hydroxyethyl]piperazine- $N^{\prime}$-[ethanesulfonic acid], $8.0 \mathrm{~g} ; \mathrm{K}_{2} \mathrm{HPO}_{4}, 1.0 \mathrm{~g} ; \mathrm{NH}_{4} \mathrm{Cl}, 0.5 \mathrm{~g} ; \mathrm{NaCl}$, $15 \mathrm{~g} ; \mathrm{MgSO}_{4} .7 \mathrm{H}_{2} \mathrm{O}, 1.0 \mathrm{~g} ; \mathrm{CaCl}_{2} .2 \mathrm{H}_{2} \mathrm{O}, 0.05 \mathrm{~g}$; metal salts solution ' 44 ', $1 \mathrm{ml}$ and vitamin solution no. 6 (Schlesner $e t$ al., 1994), $1 \mathrm{ml}$; biotin $\left(1 \mathrm{mg} \mathrm{ml}^{-1}\right), 100 \mu \mathrm{l}$. The following carbon sources were examined at $1 \mathrm{~g}^{-1}$ : gluconate, citrate, aspartate, acetate, aconitate, propionate, butyrate, pyruvate, lactate, glutarate, serine, proline, arginine, ornithine, alanine, asparagine, glutamate and glycerol. Ability to oxidize sulfite was tested in $50 \mathrm{ml}$ HEPES medium supplemented with acetate $(10 \mathrm{mM})$ under a gradual increase of concentration of 5, 10 and $20 \mathrm{mM}$, respectively. Oxidation of thiosulfate and elemental sulfur was tested as described by Sorokin (1995).

165 rDNA accession numbers of reference organisms. Octadecabacter antarcticus, U14583; Octadecabacter arcticus, U73735; Roseobacter algicola, X78315; Roseobacter denitrificans, L01784; Roseobacter litoralis, X78312; Sagitulla stellata, U58356; Sulfitobacter pontiacus, Y13155; Sargasso Sea isolate S34, U87407; Antarctic Sea strain IC
146, AF001377; and 'Methylosulfonas methylovorum', U62893.

\section{RESULTS}

\section{Molecular identification of Sulfitobacter strains}

To obtain a glimpse of the phylogenetic diversity of 680 Mediterranean Sea isolates, partial 16S rDNA sequences were analysed for 40 randomly chosen isolates followed by determination of their closest phylogenetic neighbours. The majority of these organisms belong to the $\alpha$ and $\gamma$ subclass of Proteobacteria ( 38 and $44 \%$, respectively), while the number of Gram-positive bacteria was smaller (15\%). Many strains clustered close to described species, e.g. Sulfitobacter pontiacus $(97.6-99.7 \%$ similarity) and Roseobacter algicola (97.0-100\% similarity) in the $\alpha$ subclass of Proteobacteria, and members of Pseudoalteromonas haloplanktis (99.4-100\% similarity), Alteromonas macleodii (95.5-97.1\% similarity), Marinobacter hydrocarbonoclasticus (95.6-96\% similarity) and Vibrio splendidus (95.3-97.6\% similarity) in the $\gamma$ subclass of Proteobacteria (Stackebrandt et al., 1998). Oligonucleotide probing of PCR-amplified 16S rDNA with an $\alpha$-subclass-specific probe (alpha-probe, Manz et al., 1992) showed that 280 isolates $(41 \%)$ were members of this subclass. Subsequently, the number of isolates belonging phylogenetically to the genus Sulfitobacter was determined by using an oligonucleotide probe generated to specifically identify members of the genus Sulfitobacter and isolate S34 from the Sargasso Sea (Suzuki et al., 1997). Thirty-three isolates were identified as members of this species. Thus $12.5 \%$ of all members of the $\alpha$ subclass of Proteobacteria, isolated from nine sampling points from all four mesocosms could be assigned to this taxon.

When the PCR-amplified partial 16S rDNA of about 1400 nucleotides was cleaved with the enzymes Bst UI and HhaI the restriction patterns of strain DSM $10014^{\mathrm{T}}$, strain S34 and the 33 Sulfitobacter-like isolates were identical. However, the HaeIII digest clearly indicated the presence of two strain groups. While 30 strains of group 1 showed a pattern consisting of five clearly visible fragments $(571,278,158,152$ and $78 \mathrm{bp})$, six fragments defined the pattern of group 2 strains $\mathrm{CH}-\mathrm{B} 427^{\mathrm{T}}, \mathrm{CH}-\mathrm{D} 522$ and $\mathrm{CH}-\mathrm{D} 620$. The latter result can be explained by the presence of an additional HaeIII restriction site at position 416 in the $16 \mathrm{~S}$ rDNA of these strains ( $E$. coli numbering system; Brosius et al., 1978), verified in strain $\mathrm{CH}-\mathrm{B} 427^{\mathrm{T}}$, which results in the cleavage of the $571 \mathrm{bp}$ fragment into two smaller fragments of 486 and $85 \mathrm{bp}$. It can be deduced from the presence of HaeIII restriction sites in the $16 \mathrm{~S} \mathrm{rDNA}$ of Sulfitobacter strains that three additional fragment of size 66,48 and 34 bp must be formed; however, these were not detectable on Metaphore agarose. Based upon the results of the ARDRA analysis, five strains of group 1 and one strain of group 3 were subjected to additional taxonomic analysis.

Partial 16S rDNA sequence analyses indicated that the 


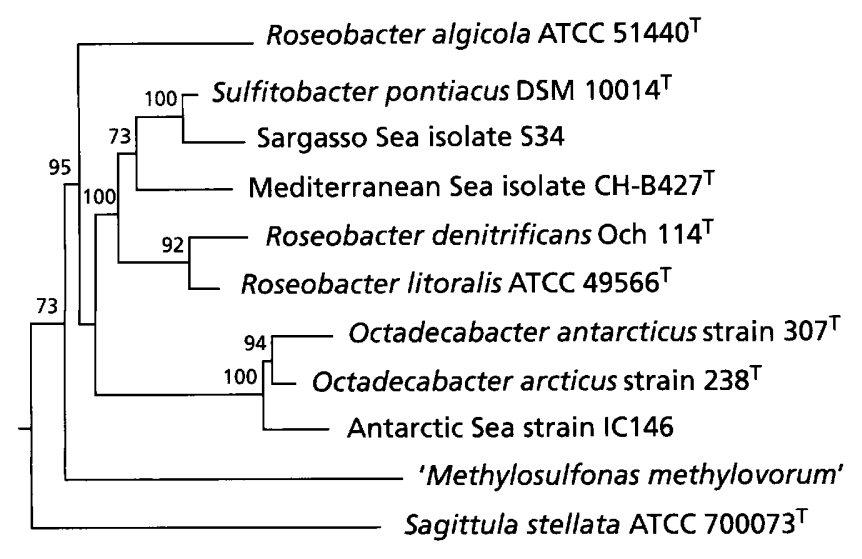

$5 \%$

Fig. 1. Dendrogram of $16 \mathrm{~S}$ rDNA relatedness showing the position of strain $\mathrm{CH}-\mathrm{B} 427^{\top}$ next to its nearest identified neighbours within the $\alpha$ subclass of the class Proteobacteria. The tree was calculated by the neighbour-joining method from almost complete sequences. The percentage of 500 bootstrap resembling that support branching points above $70 \%$ confidence is indicated. The scale bar corresponds to five nucleotide substitutions per 100 sequence positions. The tree was rooted with $E$. coli as an outgroup.

five strains of group 1, i.e. strains $\mathrm{CH}-\mathrm{A} 24, \mathrm{CH}-\mathrm{D} 261$, $\mathrm{CH}-\mathrm{B} 420, \mathrm{CH}-\mathrm{B} 423$ and $\mathrm{CH}-\mathrm{D} 520$, shared $100 \%$ similarity among each other and $99.7 \%$ similarity with the sequences of Sulfitobacter pontiacus DSM $10014^{\mathrm{T}}$ and strain S34. With $97.6 \%$ similarity, the group 2 representative strain $\mathrm{CH}-\mathrm{B} 427^{\mathrm{T}}$ was slightly less related to strain DSM $10014^{\mathrm{T}}$. For a more detailed phylogenetic analysis the almost complete sequence was analysed for isolate $\mathrm{CH}-\mathrm{B} 427^{\mathrm{T}}$, consisting of 1415 nucleotides (according to the $E$. coli nomenclature; Brosius et al., 1978). The similarity value determined for strain $\mathrm{CH}-\mathrm{B} 427^{\mathrm{T}}$ and strain DSM $10014^{\mathrm{T}}$ was $98.2 \%$. Similarity values determined for the pair Sulfitobacter pontiacus and strain $\mathrm{CH}-\mathrm{B} 427^{\mathrm{T}}$ and members of Roseobacter and Octadecabacter ranged between 93 and $96 \%$. A dendrogram of $16 \mathrm{~S}$ rDNA relationships, displaying the position of strain $\mathrm{CH}$ $\mathrm{B} 427^{\mathrm{T}}$ to its phylogenetic neighbours, is shown in Fig. 1. The branching pattern did not change with any of the algorithm applied (Maidak et al., 1997; Felsenstein, 1993).

When the almost complete sequence of strain $\mathrm{CH}$ B $427^{\mathrm{T}}$ was compared to those of strains DSM $10014^{\mathrm{T}}$ and S34 several nucleotide positions could be identified which can be considered signature nucleotides (Table 1). Most of these signatures comprise base-pair exchanges and can thus be considered genetically stable. The two signatures present in the $5^{\prime} 500$ nucleotides of the 16S rDNA of the other five Sulfitobacter isolates for which partial sequences have been generated, match those of Sulfitobacter pontiacus and strain S34.

The $\mathrm{G}+\mathrm{C}$ content of DNA was determined to be $59 \mathrm{~mol} \%$ for strain $\mathrm{CH}-\mathrm{B} 427^{\mathrm{T}}$; for group 1 strains the
Table. 1. $16 \mathrm{~S}$ rDNA signature positions of Sulfitobacter pontiacus DSM $10014^{\top}$ and strain $\mathrm{CH}-\mathrm{B} 427^{\top}$

\begin{tabular}{|lcc|}
\hline Position & DSM 10014 & CH-B427 \\
\hline Helical region $80-82 / 87-89$ & 3 bp & 4 bp \\
$418-425$ & U-A & C-G \\
$599-639$ & U-A & A-U \\
$591-648$ & U-A & C-G \\
$592-647$ & G-C & A-U \\
\hline
\end{tabular}

* Same signature is present in strain S34.

values were $60 \mathrm{~mol} \%\left(\mathrm{DSM} 10014^{\mathrm{T}}, \mathrm{CH}-\mathrm{D} 261\right.$ and $\mathrm{CH}-\mathrm{D} 520$ ) and $61 \mathrm{~mol} \%$ (for strains S34, CH-B437, $\mathrm{CH}-\mathrm{B} 420$ and $\mathrm{CH}-\mathrm{B} 423)$.

\section{Cultural and physiological properties}

All of the six isolates of groups 1 and 2, selected from the total of 33 strains that hybridized with the Sulfitobacter-specific probe and the Sargasso isolate S34, which in this study was identified as a phylogenetic relative of Sulfitobacter pontiacus, were phenotypically very similar to the type strain, DSM $10014^{\mathrm{T}}$, which was included in the tests for comparison.

All strains tested were Gram-negative, non-sporeforming, strictly aerobic and heterotrophic bacteria. Strains were both catalase- and oxidase-positive. Cells growing on marine agar at $25^{\circ} \mathrm{C}$ were rod-shaped $1-3 \mu \mathrm{m}$ in length and $0 \cdot 5-0 \cdot 8 \mu \mathrm{m}$ in diameter (Fig. 2a). Cells were motile by means of $1-5$ subpolar flagella. Bacteria grown on marine agar, supplemented with acetate, tended to form rosettes (Fig. 2b, c) and contained PHB-granula.

All strains were mesophilic $\left(4-35^{\circ} \mathrm{C}\right.$, optimum at $17-28^{\circ} \mathrm{C}$ ), neutrophilic (pH 6.5-8.5, optimum 7.0-7.5) and required $\mathrm{NaCl}$ for growth $\left(2-80 \mathrm{~g} \mathrm{l}^{-1}\right.$, optimum 15-20 $\mathrm{g}^{-1}$ ). Bacteriochlorophyll $a$ was not detected. All strains were able to grow in minimal media with and without additions of yeast extract or vitamins incubated at $28^{\circ} \mathrm{C}$ with the following compounds as sole sources of carbon and energy: glucose, mannitol, gluconate, adipate, acetate, malate, pyruvate, lactate, propionate, butyrate, serine, proline, ornithine, alanine, asparagine, glutamate, phenylacetate and glycerol. Growth of strain $\mathrm{CH}-\mathrm{B} 427^{\mathrm{T}}$ at $25^{\circ} \mathrm{C}$ on marine agar plates supplemented with acetate was slower compared to the other strains. Strains were not able to reduce nitrate; glutarate, cis-aconitate, tryptophan, caprate, urea, arabinose and mannose were not utilized. Glucose was not fermented. Weak growth was detected with aspartate. No oxidation of thiosulfate or elemental sulfur was observed. Utilization of citrate and maltose was stimulated in media containing yeast extract or biotin. Utilization of $\mathrm{N}$-acetylglucosamine and activity of arginine hydrolase, $\beta$-glucosidase and gelatine hydrolase were induced after a longer incubation period $(>3 \mathrm{~d})$. 

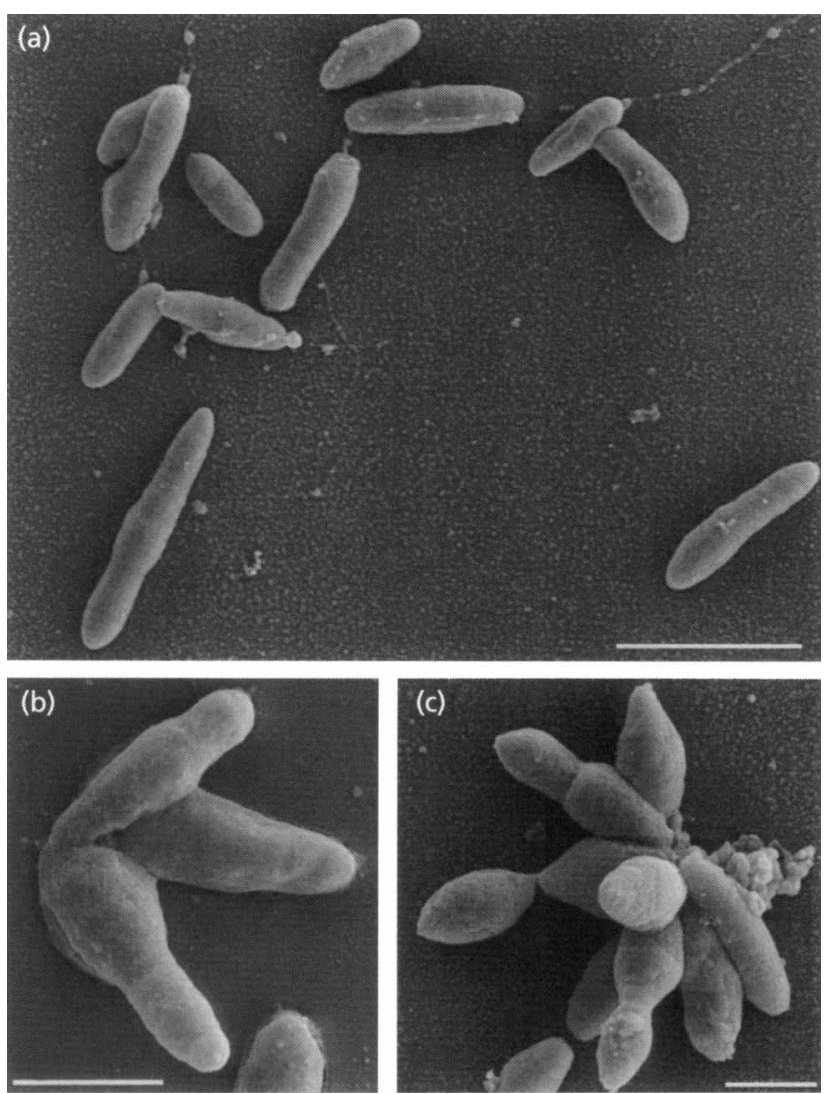

Fig. 2. Electron micrographs of strain $\mathrm{CH}-\mathrm{B} 427^{\top}$ showing (a) different cell morphology (bar, $2 \mu \mathrm{m}$ ) and (b, c) rosette formation (bars, $1 \mu \mathrm{m}$ ). Cells were grown overnight on marine broth supplemented with acetate.
Compared to Sulfitobacter pontiacus DSM 10014 ${ }^{\mathrm{T}}$, strain $\mathrm{CH}-\mathrm{B} 427^{\mathrm{T}}$ showed higher cell density in acetate (10 mM) - supplemented HEPES medium after short adaptation to sulfite concentrations of $5 \mathrm{mM}$ and of $10 \mathrm{mM}$. None of the Sulfitobacter strains were able to grow in media containing $20 \mathrm{mM}$ sulfite.

\section{Fatty acid analysis}

The main fatty acids determined for Sulfitobacter pontiacus DSM $10014^{\mathrm{T}}$ and five related strains grown in $\mathrm{TBS} / \mathrm{NaCl}$ medium were cis-11 octadecenoic acid $(>72 \%)$, followed by hexadecanoic acid (4-7\%) (Table 2). All other fatty acids occurred in less than $5 \%$. While in strain $\mathrm{CH}-\mathrm{B} 427^{\mathrm{T}}$ the growth medium used had no influence on the relative ratio of the fatty acid composition, a significant change was observed in the other strains of Sulfitobacter when grown on Marine agar. Here the percentage of cis11-18:1 fatty acid decreased from about $80 \%$ to $65-75 \%$, while the percentage of 10:0-3-OH, cis $9-16: 1$ and 16:0 fatty acids increased (not shown). The dendrogram of fatty acid relatedness, based upon the data obtained from cells grown in $\mathrm{NaCl}$-supplemented TSB medium, clearly indicates the separate position of strain $\mathrm{CH}$ B427 ${ }^{\mathrm{T}}$ (Fig. 3).

\section{DNA-DNA hybridization}

Determination of DNA relatedness by the spectrophotometric method was performed with the type strain of Sulfitobacter pontiacus DSM $10014^{\mathrm{T}}$ and the six representatives of ARDRA groups 1 and 2. The

Table 2. Percentage fatty acid composition of some Sulfitobacter strains

\begin{tabular}{|c|c|c|c|c|c|c|}
\hline Fatty acid* & DSM $10014^{T}$ & CH-A24 & CH-D261 & CH-D520 & S34 & CH-B427 \\
\hline $10: 0-3-\mathrm{OH}$ & $3 \cdot 5$ & $2 \cdot 6$ & $2 \cdot 6$ & $2 \cdot 5$ & $3 \cdot 3$ & $2 \cdot 5$ \\
\hline $12: 0-3-\mathrm{OH}$ & 0.7 & $0 \cdot 6$ & $0 \cdot 7$ & $0 \cdot 6$ & $0 \cdot 7$ & $0 \cdot 6$ \\
\hline ECL13.521 & & & $1 \cdot 0$ & $3 \cdot 9$ & & $3 \cdot 3$ \\
\hline $14: 0$ & & & & & & $0 \cdot 7$ \\
\hline $15: 0$ & & $0 \cdot 4$ & $0 \cdot 3$ & & $0 \cdot 4$ & $0 \cdot 5$ \\
\hline ECL $15 \cdot 278$ & $2 \cdot 6$ & $2 \cdot 0$ & 1.9 & $1 \cdot 8$ & $2 \cdot 4$ & 1.9 \\
\hline cis7-16:1 & & & & & & 1.9 \\
\hline cis $9-16: 1$ & $1 \cdot 3$ & $0 \cdot 8$ & $1 \cdot 1$ & $1 \cdot 0$ & $1 \cdot 0$ & $1 \cdot 0$ \\
\hline $16: 0$ & $4 \cdot 8$ & $4 \cdot 5$ & $5 \cdot 1$ & $4 \cdot 7$ & $5 \cdot 1$ & $6 \cdot 1$ \\
\hline cis9-17:1 & $1 \cdot 0$ & $1 \cdot 3$ & $1 \cdot 1$ & $1 \cdot 2$ & $1 \cdot 0$ & $1 \cdot 2$ \\
\hline $17: 0$ & $1 \cdot 2$ & $1 \cdot 4$ & $1 \cdot 1$ & $1 \cdot 2$ & $1 \cdot 2$ & $0 \cdot 9$ \\
\hline cis9-18:1 & & & & & & $1 \cdot 7$ \\
\hline cis11-18:1 & $81 \cdot 5$ & $80 \cdot 4$ & $78 \cdot 6$ & $76 \cdot 7$ & $79 \cdot 1$ & $72 \cdot 4$ \\
\hline $18: 0$ & 0.7 & 0.7 & $0 \cdot 7$ & 0.6 & 0.6 & $0 \cdot 7$ \\
\hline 10met-18:1 & $2 \cdot 7$ & $4 \cdot 7$ & $5 \cdot 0$ & $5 \cdot 1$ & $4 \cdot 0$ & $2 \cdot 6$ \\
\hline 18 met-18:1 & & & & & & $1 \cdot 4$ \\
\hline ECL18.847 & & $0 \cdot 6$ & $0 \cdot 8$ & $0 \cdot 7$ & $0 \cdot 9$ & \\
\hline 10met-19:0 & & & & & $0 \cdot 3$ & \\
\hline
\end{tabular}

* 16:0, hexanecanoic acid (palmitic acid); cis11-18:1, cis-11 octadecenoic acid (cis-vaccenic acid); 10met-18:1, 10-methyl octadecenoic acid; $12: 0-3-\mathrm{OH}, 3$-hydroxy decanoic acid ( $\beta$-hydroxy lauric acid). ECL15.278, unknown fatty acid showing an equivalent chain-length of $15 \cdot 278$. 


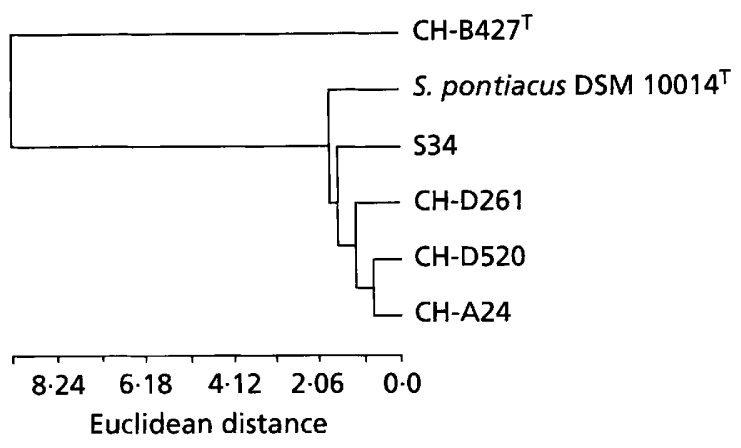

Fig. 3. Cluster analysis of fatty acid profiles of Sulfitobacter pontiacus and related isolates. The branching pattern was constructed from the Euclidean distance coefficients by the unweighted pair group method with arithmetic averages. Analysis was done using the standard MIS software (Microbial ID).

Table 3. Percentage DNA-DNA homology between Sulfitobacter-like isolates and Sulfitobacter pontiacus DSM $10014^{\top}$ as determined by spectroscopic DNA-DNA hybridization

\begin{tabular}{|lc|}
\hline Strain & $\begin{array}{c}\text { Homolgy } \\
\text { with DSM } \\
\mathbf{1 0 0 1 4}^{\mathrm{T}}\end{array}$ \\
\hline CH-A24 & 100 \\
CH-D261 & $82 \cdot 4$ \\
CH-B420 & $92 \cdot 3$ \\
CH-B423 & 100 \\
CH-D520 & $88 \cdot 9$ \\
CH-B427 & $46 \cdot 1$ \\
\hline
\end{tabular}

data revealed that those isolates that shared with DSM $10014^{\mathrm{T}}$ identical ARDRA patterns, high fatty acid relatedness, and almost identical partial 16S rDNA similarities (group 1 strains) also shared DNA-DNA similarity values of higher than $82 \%$. The only lower value of $46 \%$ similarity was obtained for Sulfitobacter pontiacus DSM $10014^{\mathrm{T}}$ and strain $\mathrm{CH}-\mathrm{B} 427^{\mathrm{T}}$ (group 2 strain).

\section{DISCUSSION}

The occurrence of a high number of isolates from mesocosm experiments with Mediterranean coastal seawater that phylogenetically resembled Sulfitobacter pontiacus was unexpected as this species was hitherto represented only by two strains from the Black Sea (Sorokin, 1995). The fact that this taxon has not been reported among the cultured strains from other recently studied marine environments may be due to the unavailability of the 16S rDNA sequence of $S$. pontiacus from a public database. The inclusion of published sequences from the studies of the Sargasso Sea isolate S34 (Suzuki et al., 1997) indeed indicates that bacteria related to Sulfitobacter also occur in other oceans.

Of the 33 strains identified to be closely related to Sulfitobacter pontiacus DSM $10014^{\mathrm{T}}$ by oligonucleotide probing, 30 strains share with the type strain identical ARDRA patterns generated by three different restriction enzymes. As the five strains selected from the 30 strains share with Sulfitobacter pontiacus high phylogenetic (including DNA-DNA similarity values above $80 \%$ ), chemotaxonomic and phenotypic similarities, it can be deduced that all of these strains belong to the same species. The other three strains differ from the type strain and related isolates in the ARDRA pattern generated by restriction with HaeIII. Of these three strains, $\mathrm{CH}-\mathrm{B} 427^{\mathrm{T}}$ was investigated more thoroughly and the data reveal its taxonomic separatedness in that it differs from the type strain of $S$. pontiacus in the primary structure of $16 \mathrm{~S}$ rDNA, quantitative composition of fatty acids and moderate DNA-DNA similarity of only $46 \%$. Clear-cut phenotypic differences, traditionally used to differentiate species from each other, have not been found. As we consider each nucleotide of the primary structure of a evolutionary conservative gene, such as the $16 \mathrm{~S}$ rDNA, to be a genetically stable and reproducibly identifiable phenotypic property, strain $\mathrm{CH}-\mathrm{B} 427^{\mathrm{T}}$ can clearly be differentiated from the type strain of Sulfitobacter pontiacus and related strains (Table 1). We therefore propose to classify strain $\mathrm{CH}-\mathrm{B} 427^{\mathrm{T}}$ as the type strain of a new species of the genus Sulfitobacter, Sulfitobacter mediterraneus.

\section{Description of Sulfitobacter mediterraneus sp. nov.}

Sulfitobacter mediterraneus (med.i.ter.ra.ne'us. N.L. adj. mediterraneus of the Mediterranean Sea).

Gram-negative, non-spore-forming, strictly aerobic and heterotrophic bacteria. Catalase- and oxidasepositive. Cells grown on marine agar at $25^{\circ} \mathrm{C}$ are rodshaped, $1-3 \mu \mathrm{m}$ in length and $0.5-0.8 \mu \mathrm{m}$ in diameter. Colonies on Marine agar are $1.2-1.4 \mathrm{~mm}$ in diameter, circular, convex, with entire or undulate margin, translucent and cream-coloured. Cells are motile by means of 1-5 subpolar flagella. Bacteria grown on marine agar, supplemented with acetate, tend to form rosettes and contain PHB-granula. Mesophilic. Growth occurs between $4-35^{\circ} \mathrm{C}$, with an optimum at $17-28^{\circ} \mathrm{C}$. Neutrophilic (pH $6 \cdot 5-8 \cdot 5$, optimum $7 \cdot 0-7 \cdot 5$ ). $\mathrm{NaCl}\left(2-80 \mathrm{~g} \mathrm{l}^{-1}\right.$, optimum 15-20 $\left.\mathrm{g}^{-1}\right)$ is required for growth. In minimal media with or without the addition of yeast extract or vitamins, growth occurs at $28^{\circ} \mathrm{C}$ with glucose, mannitol, gluconate, adipate, acetate, malate, pyruvate, lactate, propionate, butyrate, serine, proline, ornithine, alanine, asparagine, glutamate and glycerol. Glutarate, cis-aconitate, tryptophan, caprate, urea, arabinose and mannose are not utilized. Weak growth is detected with aspartate. Nitrate is not reduced. Glucose is not fermented. No growth with thiosulfate or elemental sulfur. Utilization of citrate and maltose is stimulated in media containing yeast 
extract or biotin. Utilization of $N$-acetylglucosamine and activity of arginine hydrolase, $\beta$-glucosidase and gelatine hydrolase are induced after a longer incubation period $(>3 \mathrm{~d})$. Phenylacetate is utilized after $24 \mathrm{~h}$ incubation at $25^{\circ} \mathrm{C}$. Growth on $10 \mathrm{mM}$ sulfite in acetate $(10 \mathrm{mM})$-supplemented HEPES medium. In TSB medium containing 3\% $\mathrm{NaCl}$ the main fatty acid is $c i s-11$ octadecenoic acid. Hexadecanoic acid occurs in smaller amounts. Bacteriochlorophyll $a$ is not present. The $\mathrm{G}+\mathrm{C}$ content is $59 \mathrm{~mol} \%$. Signature nucleotides for $16 \mathrm{~S}$ rDNA, are located at positions 418-425 (C-G), 591-648 (C-G), 592-647 (A-U) and 599-639 (A-U). Type strain CH-B427 ${ }^{\mathrm{T}}$ (= DSM $12244^{\mathrm{T}}$ ) isolated from coastal waters of the west Mediterranean Sea.

We thank Josef Vives-Rego and Theresa Guindualain for providing us with strains isolated during the CHABADA project and Marcelino T. Suzuki for providing us with strain S34. This work was supported by a grant from the European Commission, no. MAS3-CT96-0047.

\section{REFERENCES}

Bowman, J., McCammon, S. A., Brown, M. V., Nichols, D. S. \& McMeekin, T. A. (1997). Diversity and association of psychrophilic bacteria in Antarctic sea ice. Appl Environ Microbiol 63,

Benlloch, S., Rodriguez-Valera, F. \& Martinez-Murcia, A. J. (1995). Bacterial diversity in two coastal lagoons deduced from $16 \mathrm{~S}$ rDNA PCR amplification and partial sequencing. FEMS Microbiol Ecol 18, 267-280.

Brosius, J., Palmer, M. L., Kennedy, P. J. \& Noller, H. F. (1978). Complete nucleotide sequence of the $16 \mathrm{~S}$ ribosomal RNA gene from Escherichia coli. Proc Natl Acad Sci USA 75, 4801-4805.

Cashion, P., Holder-Franklin, M. A., McCully, J. \& Franklin, M. (1977). A rapid method for the base ratio determination of bacterial DNA. Anal Biochem 81, 461-466.

DeSoete, G. (1983). A least squares algorithm for fitting additive trees to proximity data. Psychometrika 48, 621-626.

Escara, J. F. \& Hutton, J. R. (1980). Thermal stability and renaturation of DNA in dimethylsulphoxide solutions: acceleration of renaturation rate. Biopolymers 19, 1315-1327.

Felsenstein, J. (1993). PHYLIP (phylogenetic inference package) version 3.5.1. Department of Genetics, University of Washington, Seattle, USA.

Gerhardt, P., Murray, R. G. E., Wood, W. A. \& Krieg, N. R. (1994). Methods for General Molecular Bacteriology. Washington, DC: American Society for Microbiology

Gonzales, J. M., Mayer, F., Moran, M. A., Hodson, R. E. \& Whitman, W. B. (1997). Sagittula stellata gen. nov., sp.nov., a lignin-transforming bacterium from a coastal enviroment. Int $J$ Syst Bacteriol 47, 773-780.

Gosink, J. J., Herwig, R. P. \& Staley, J. T. (1997). Octadecabacter arcticus gen. nov., spec. nov. and $O$. antarcticus sp. nov., nonpigmented, psychrophilic gas vacuolated bacteria from polar sea ice and water. Syst Appl Microbiol 20, 356-365.

Heimbrook, M. E., Wong, W. L. L. \& Campbell, G. (1989). Staining bacterial flagella easily. J Clin Microbiol 27, 2612-2615.

Huß, V. A. R., Festl, H. \& Schleifer, K. H. (1983). Studies on the spectrophotometric determination of DNA hybridization from renaturation rates. Syst Appl Microbiol 4, 184-192.

Jahnke, K.-D. (1992). BASIC computer program for evaluation of spectroscopic DNA renaturation data from GILFORD SYSTEM 2600 spectrophotometer on a PC/XT/AT type personal computer. J Microbiol Methods 15, 61-73.

Jukes, T. H. \& Cantor, C. R. (1969). Evolution of protein molecules. In Mammalian Protein Metabolism, vol, 3, pp. 21-132. Edited by H. N. Munro. New York: Academic Press.

Kuykendall, L. D., Roy, M. A., O'Neill, J. J. \& Devine, T. E. (1988). Fatty acids, antibiotic resistance, and deoxyribonucleic acid homology groups of Bradyrhizobium japonicum. Int $J$ Syst Bacteriol 38, 358-361.

Lane, D. J. (1991). 16S/23S rRNA sequencing. In Nucleic Acid Techniques in Bacterial Systematics, pp. 125-175. Edited by E. Stackebrandt \& M. Goodfellow. Chichester: Wiley.

Maidak, B. L., Olsen, G. J., Larsen, N., Overbeek, R., McCaughey, M. J. \& Woese, C. R. (1997). The RDP (Ribosomal Database Project). Nucleic Acids Res 25, 109-111.

Manz, W., Amann, R., Ludwig, W., Wagner, M. \& Schleifer, K.-H. (1992). Phylogenetic oligonucleotide probes for the major subclasses of proteobacteria : problems and solutions. Syst Appl Microbiol 15, 593-600.

Mesbah, M., Premachandran, U. \& Whitman, W. B. (1989). Precise measurement of the $\mathrm{G}+\mathrm{C}$ content of deoxyribonucleic acid by high-performance liquid chromatography. Int $J$ Syst Bacteriol 39, 159-167.

Miller, L. T. (1982). A single derivatization method for bacterial fatty acid methyl esters including hydroxy acids. $J$ Clin Microbiol 16, 584-586.

Pukall, R., Brambilla, E. \& Stackebrandt, E. (1998). Automated fragment length analysis of fluorescently-labeled 16S rDNA after digestion with 4-base cutting restriction enzymes. $J$ Microbiol Methods 32, 55-64.

Rainey, F. A., Ward-Rainey, N., Kroppenstedt, R. M. \& Stackebrandt, E. (1996). The genus Nocardiopsis represents a phylogenetically coherent taxon and a distinct actinomycete lineage: proposal of Nocardiopsaceae fam. nov. Int J Syst Bacteriol 46,

Schlesner, H. (1994). The development of media suitable for the microorganisms morphologically resembling Planctomyces ssp., Pirellula ssp., and other Planctomycetales from various aquatic habitats using dilute media. Syst Appl Microbiol 17,

Sorokin, D. Y. (1995). Sulfitobacter pontiacus gen. nov., sp. nov. - a new heterotrophic bacterium from the Black Sea, specialized on sulfite oxidation. Microbiology (English translation of Mikrobiologiya) 64, 295-305.

Stackebrandt, E., Lebaron, P., Troussilier, M., Courties, C., Servais, P., Vives-Rego, J., Muyzer, G., Pukall, R., Lehnberg, B., Buntefuß, D., Päuker, O., Ulrichs, G., Bernard, L., Guindulain, T. \& Schäfer, H. (1998). Assessment of changes of diversity among Mediterranean prokaryotes subjected to eutrophying conditions. In Third European Marine Science and Technology Conference, pp. 764-777. Edited by K.-G. Barthel, H. Barth, M. BohleCarbonell, C. Fragakis, E. Lipiatou, P. Martin, G. Ollier \& M. Weydert. Brussels : European Commission.

Suzuki, M. T., Rappe, M. S., Haimberger, Z. W., Winfield, H., Adair, N., Strobel, J. \& Giovannoni, S. (1997). Bacterial diversity among small-subunit rRNA gene clones and cellular isolates from the same seawater sample. Appl Environ Microbiol 63, 